\title{
Orbital Leiomyosarcoma After Bilateral Retinoblastoma Treated With Chemotherapy And Radiotherapy
}

\author{
A Smyth, E. M. McElnea, P. A. McKelvie, A. A. McNab
}

Abstract - A 23-year old man presented with a swelling medially in his left orbit. He had had bilateral retinoblastoma as an infant and was treated with bilateral enucleation, chemotherapy and radiotherapy. Histological examination confirmed the lesion to be leiomyosarcoma. A genetic defect in the RB1 tumour suppressor gene underlies the development of hereditary retinoblastoma and renders patients at substantially increased risk of developing subsequent non-ocular malignancies including soft tissue sarcomas. This risk is enhanced by radiotherapy particularly if administered before the age of one year. Awareness, by both patients and healthcare professionals, of this risk of secondary malignancy, is extremely important. Identification and aggressive investigation of new symptoms and signs may allow for the earlier detection of secondary malignancy which may, in turn, improve outcomes.

Index Terms - Leiomyosarcoma; Radiotherapy; Retinoblastoma.

\section{CASE REPORT}

A 23-year old man presented with two years history of swelling at his left medial canthus associated with intermittent pain. At examination, a firm, smooth swelling, adherent to underlying structures, was noted medially in the left orbit. Axial MRI showing the same can be seen in Fig. 1. The nasolacrimal system was patent.

He had had bilateral retinoblastoma as an infant and was treated with bilateral enucleation, chemotherapy and radiotherapy. The clinical notes detailing the exact nature of the latter two of these treatments which had been undertaken in another hospital, could not be located.

Histopathological analysis of a sample taken at biopsy of the mass identified a pleomorphic sarcoma with high cellularity, mitotic activity and eosinophilic cytoplasm (Fig. 2). Immunohistochemistry showed strong diffuse reactivity for desmin and smooth muscle actin consistent with high grade leiomyosarcoma (Fig. 3).

Further resection removed the medial orbital contents, the bone of the lacrimal fossa and nasal mucosa. Tumour was found at the resection margins. Further, wider, local resection involving medial maxillectomy and ethmoidectomy as well as removal of more of the medial

Published on June 23, 2020.

A Smyth, Mater Misericordiae University Hospital, Ireland.

(corresponding e-mail: aoife.smyth@ ucdconnect.ie).

E. M. McElnea, Royal Victorian Eye and Ear Hospital, Australia.

(e-mail: mcelneaelizabeth ${ }^{\circledR}$ gmail.com)

P. A. McKelvie, St Vincents Hospital, Australia

(e-mail: penny.mckelvie@ ${ }^{@}$ sva.org.au).

A. A. McNab, University of Melbourne, Australia.

(e-mail: amcnab@bigpond.com) orbital contents was undertaken. No adjuvant treatment was given.

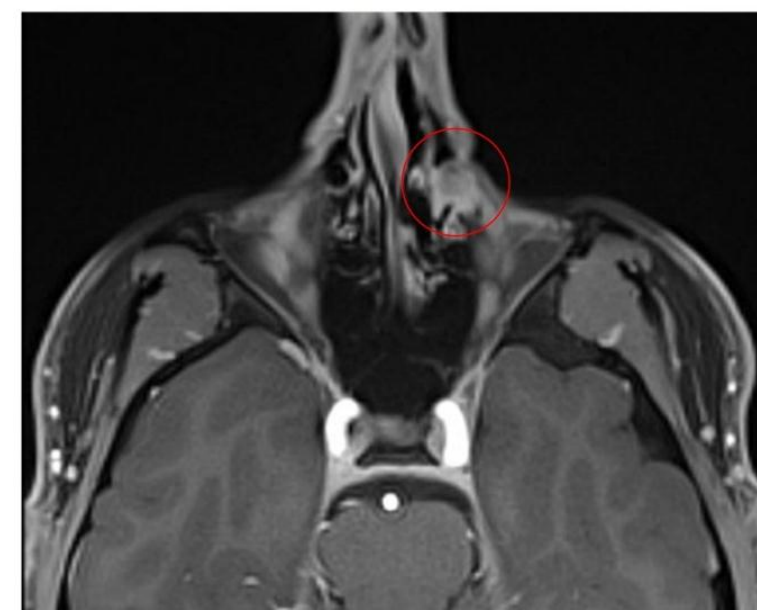

Fig. 1. Axial MRI of the orbits showed a small well-defined lesion in the medial portion of the left orbit.

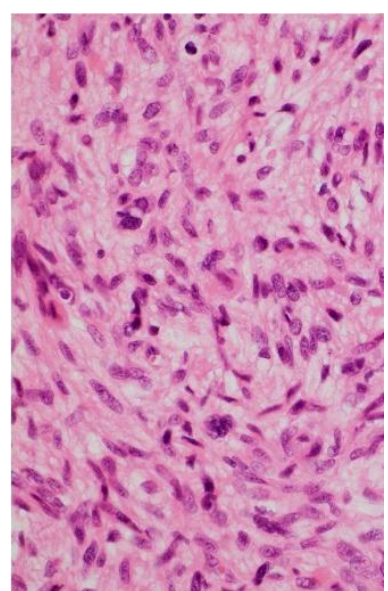

Fig. 2. Haematoxylin and eosin. 400X. Highly cellular leiomyosarcoma with high mitotic activity.

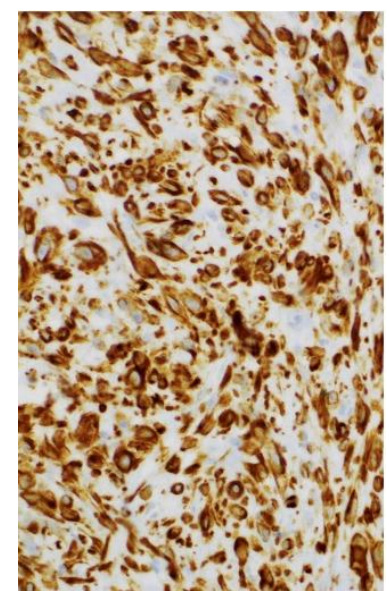

Fig. 3. Desmin immunohistochemistry. 400X. Strong diffuse reactivity. 
The patient recovered. Serial magnetic resonance imaging studies have not demonstrated local or distant disease at one year following this diagnosis.

\section{DISCUSSION}

With a cumulative lifetime incidence of one in 18,000 to 30,000 live births worldwide [1], retinoblastoma is the most common primary intraocular malignancy of childhood and approximately the tenth most common paediatric cancer [2]. It is caused by a neoplastic proliferation of retinoblasts immature cells of the retina. A mutation in both alleles of the retinoblastoma 1 (RB1) tumour suppressor gene on chromosome 13 is required for the development of retinoblastoma [3]. Hereditary and non-hereditary forms exist. In hereditary or 'germline' retinoblastoma, one mutant allele is inherited and another 'normal' allele undergoes mutation following conception.

Multiple ocular tumours bilaterally are the hallmark of hereditary retinoblastoma. Since RB1 acts as a tumour suppressor gene in all cells of the body, and not just the cells of the immature retina, and as each of their cells carries at least one mutant RB1 allele, patients with hereditary retinoblastoma are well recognized to be at high risk of developing second non-ocular cancers later in life [4].

Indeed, patients who have been successfully treated for retinoblastoma have an approximately ten-fold increased tendency to develop second non-ocular malignant tumours. The cumulative risk of developing a second tumour 50 years after the diagnosis of hereditary retinoblastoma is estimated to be between 36\% [5] and 51\% [6]. In 1993 Eng et al. reported that patients with a history of bilateral retinoblastoma had a $26 \%$ risk of mortality from a second malignancy by 40 years after their original diagnosis [7].

This risk for the subsequent development of second cancers is enhanced by radiotherapy [6]. The risk is greatest if children are radiated in the first year of life with these children being between two and eight times as likely to develop second cancers as those radiated after the age of one year 8 . The risk appears to be particularly great for the development of sarcomas $-76 \%$ and $48 \%$ of those with hereditary retinoblastoma radiated, compared to $33 \%$ and $8 \%$ not radiated, develop sarcoma before and after 25 years respectively [9].

Two thirds of 'second' tumours in patients with bilateral retinoblastoma treated with radiation arise within the field of radiation [10]. A dose-response relationship for the development of secondary sarcomas, particularly of the head and neck, after radiation, has also been demonstrated so that patients treated for retinoblastoma with $60 \mathrm{~Gy}$ or more had 11 times the risk of patients treated with less than 5 Gy [6].

Additionally, hereditary retinoblastoma patients treated with radiation and chemotherapeutic alkylating agents e.g. triethylenemelamine (TEM) and cyclophosphamide have a significantly higher risk of developing leiomyosarcomas than those treated with radiation alone [11]. A case-control analysis of a United Kingdom based cohort of childhood cancer survivors also reported a positive dose-response relationship for the development of soft tissue sarcoma among patients treated with alkylating agents [12]. Of note, TEM is now no longer used [5].
Leiomyosarcomas are smooth muscle derived tumours occurring mostly in the gastrointestinal and female genital tracts and vascular tissues because of the preponderance of smooth muscle at these sites [13]. They account for $6.5 \%$ of all soft tissue sarcomas with only $3 \%$ of these arising in the head and neck [14]. Leiomyosarcoma is rarely a primary tumour of the eye and adnexa although it has been reported in the conjunctiva, uvea, and orbit [15], [16] where it is thought to arise from vascular tissue or fascial septa of the orbit or smooth muscle in the eyelid. Orbital leiomyosarcoma may also represent extension from the paranasal sinuses, metastasis from a distant site or occur on a background of radiotherapy as here [17]. Reports of other cases of orbital leiomyosarcoma after radiation therapy for hereditary retinoblastoma are summarized in Table I [18] [23].

Surgical resection with adequate margins of uninvolved tissue is the recommended treatment for leiomyosarcoma. Although many tumours initially appear to be well circumscribed, the tumour may be friable or unencapsulated [24] preventing complete surgical resection and the persistence of leiomyosarcomas despite initial wide resection as in the case described here and/or the high incidence of local recurrence illustrates the infiltrative and aggressive nature of this malignancy [25].

Orbital exenteration with removal of any involved bone, has been suggested as the treatment of choice for orbital leiomyosarcoma if no metastatic disease is demonstrable. Management can however be even more challenging when leiomyosarcoma arises in an orbit containing the patient's only eye which may or may not retain good vision as in several of the cases already described. For tumour arising in the anterior orbit, as here, wide local resection may be an appropriate alternative [26].

Adjunctive therapy can be considered. One patient already reported received neo-adjunctive radiotherapy and chemotherapy with doxorubicin and cyclophosphamide which resulted in a reduction in size of the tumour. Uneventful surgical excision of this patient's tumour followed [22].

The prognosis thus depends largely on the location and extent of the tumour and in turn, the potential for radical resection - complete resection is associated with a high rate of survival. In patients with retinoblastoma previously treated with radiation who developed secondary skull base malignancy for which they underwent surgical resection, five and ten years survival rates were $68 \%$ and $51 \%$ respectively, the latter estimated by Kaplan Meier analysis, [27]. $71 \%$ received chemotherapy, $41 \%$ radiotherapy and $24 \%$ required salvage surgery for recurrent disease. A selection bias in this study, was however acknowledged as only tumours amenable to surgical resection were included.

Indeed, the number of cases of post radiation orbital leiomyosarcoma reported are so small as to make suggestions regarding appropriate management difficult. For the same reason, whether earlier, radical surgery and/or multimodality adjunctive therapy would significantly alter the long-term prognosis remains to be demonstrated. 


\begin{tabular}{|c|c|c|c|c|c|c|c|}
\hline $\begin{array}{c}\text { Age } \\
\text { (months) at } \\
\text { diagnosis } \\
\text { RB } \\
\end{array}$ & Sex & RB treatment & $\begin{array}{c}\text { Age } \\
\text { (years) at } \\
\text { diagnosis } \\
\text { LMS }\end{array}$ & $\begin{array}{l}\text { Location } \\
\text { LMS }\end{array}$ & Treatment & Outcome & $\begin{array}{c}\text { Reference } \\
\text { No. }\end{array}$ \\
\hline & $\mathrm{M}$ & $\begin{array}{l}\text { L enucleation. } \\
\text { R EBRT } 32 \text { Gy. }\end{array}$ & 23 & $\begin{array}{c}\text { R. lower } \\
\text { eyelid and } \\
\text { inferior orbit. }\end{array}$ & $\begin{array}{c}\text { Wide local resection. PDR } \\
\text { brachytherapy } 50 \text { Gy }\end{array}$ & Well 2.5 years following diagnosis & [18] \\
\hline & M & $\begin{array}{l}\text { B/L radiotherapy } \\
45 \mathrm{GY} \text {. } \\
\text { Additional L. } 45 \\
\text { Gy } 2 \text { years later. }\end{array}$ & 26 & $\begin{array}{l}\text { R. inferior } \\
\text { orbit. }\end{array}$ & $\begin{array}{l}\text { Biopsy. Exenteration. } \\
\text { Further excision of } \\
\text { residual tumour with } \\
\text { extension to sinuses }\end{array}$ & $\begin{array}{l}\text { No details } \\
\text { given }\end{array}$ & [19] \\
\hline \multirow[t]{3}{*}{8} & M & $\begin{array}{l}\text { L. enucleation. } \\
\text { R. } 80 \mathrm{~Gy}+32 \\
\text { Gy for } \\
\text { recurrence. }\end{array}$ & 29 & $\begin{array}{l}\text { R. superior } \\
\text { orbit. }\end{array}$ & $\begin{array}{l}\text { Excision of an } \\
\text { encapsulated mass }\end{array}$ & No details given & [20] \\
\hline & M & $\begin{array}{l}\text { B/L enucleation, } \\
\text { radiotherapy, } \\
\text { chemotherapy. }\end{array}$ & 29 & $\begin{array}{l}\text { R. maxillary } \\
\text { sinus and } \\
\text { inferior orbit. }\end{array}$ & $\begin{array}{l}\text { Exenteration, } \\
\text { maxillectomy, } \\
\text { radiotherapy }\end{array}$ & & [21] \\
\hline & $\mathrm{F}$ & $\mathrm{B} / \mathrm{L}$ radiotherapy. & 15 & Left orbit. & & & {$[22]$} \\
\hline 12 & $\mathrm{~F}$ & $\begin{array}{l}\text { R. enucleation. } \\
\text { L. } 16 \text { Gy } \\
\text { radiotherapy. }\end{array}$ & 22 & $\begin{array}{l}\text { Subcutaneous } \\
\text { tissue L. } \\
\text { inferonasal } \\
\text { periorbital } \\
\text { area. } \\
\end{array}$ & $\begin{array}{l}\text { Radiotherapy } 60 \mathrm{~Gy} . \\
\text { Doxorubicin and } \\
\text { cyclophosphamide. } \\
\text { Excision residual mass }\end{array}$ & $\begin{array}{c}\text { Nephrectomy, } \\
\text { radiotherapy, chemotherapy for } \\
\text { renal cell carcinoma at } 29 \text { years. } \\
\text { No recurrence or metastatic spread } \\
\text { from either neoplasm } \\
\end{array}$ & [23] \\
\hline 9 & $\mathrm{~F}$ & $\begin{array}{l}\text { R. enucleation. L } \\
\text { Radiotherapy. }\end{array}$ & 40 & $\begin{array}{l}\text { L. inferior } \\
\text { orbit. }\end{array}$ & $\begin{array}{l}\text { Neo-adjuvant adriblastin, } \\
\text { ifosfamide. IMRT 66Gy }\end{array}$ & $\begin{array}{c}\text { Local recurrence at } 4 \text { years. } \\
\text { Palliative chemotherapy etoposide, } \\
\text { ifosfamide. Death with hepatic, } \\
\text { pulmonary and cutaneous } \\
\text { metastases } 6.5 \text { years following } \\
\text { diagnosis }\end{array}$ & [23] \\
\hline
\end{tabular}

\section{CONCLUSION}

Advances in the treatment of retinoblastoma have contributed to improvements in survival, from a 3-year survival rate of $76 \%$ in the 1970 s to a 5-year survival rate of $97 \%$ since the 1990s [28], [29] so that excellent survival for treated retinoblastoma patients can now be anticipated.

A genetic defect in the RB1 tumour suppressor gene underlies the development of this disease and renders these patients at substantially increased risk of developing subsequent malignancies including soft tissue sarcomas.

Awareness of this risk of secondary malignancy, by both patients and healthcare professionals, is of the utmost importance. Identification and aggressive investigation of new symptoms and signs may allow for the earlier detection of secondary malignancy which may improve outcomes.

\section{REFERENCES}

[1] Tamboli A, Podgor MJ, Horm JW. The incidence of retinoblastoma in the United States: 1974 through 1985. Arch Ophthalmol. 1990;108(1):128-32.

[2] Gatta G, Botta L. Childhood cancer survival in Europe: action is needed. Epidemiol Prev. 2013;37(6):363-6.

[3] Harbour JW. Molecular basis of low-penetrance retinoblastoma. Arch Ophthalmol. 2001;119(11):1699-704.

[4] Dunkel IJ, Gerald WL, Rosenfield NS, Strong EW, Abramson DH, Ghavimi F. Outcome of patients with a history of bilateral retinoblastoma treated for a second malignancy: the Memorial SloanKettering experience. Med Pediatr Oncol. 1998;30(1):59-62.

[5] Kleinerman RA, Tucker MA, Tarone RE, Abramson DH, Seddon JM, Stovall $\mathrm{M}$ et al. Risk of new cancers after radiotherapy in long-term survivors of retinoblastoma: an extended follow-up. J Clin Oncol 2005;23(10):2272-9.

[6] Wong FL, Boice JD Jr, Abramson DH, Tarone RE, Kleinerman RA, Stovall $\mathrm{M}$ et al. Cancer incidence after retinoblastoma. Radiation dose and sarcoma risk. JAMA. 1997;278(15):1262-7.

[7] Eng C, Li FP, Abramson DH, Ellsworth RM, Wong FL, Goldman $\mathrm{MB}$ et al. Mortality from second tumors among long-term survivors of retinoblastoma. J Natl Cancer Inst. 1993;85(14):1121-8.

[8] Abramson DH, Schefler AC. Update on retinoblastoma. Retina. 2004;24(6):828-48
[9] Kleinerman RA, Tucker MA, Abramson DH, Seddon JM, Tarone RE, Fraumeni JF Jr. Risk of soft tissue sarcomas by individual subtype in survivors of hereditary retinoblastoma. J Natl Cancer Inst 2007;99(1):24-31

[10] Ryan RS1, Gee R, O'Connell JX, Harris AC, Munk PL. Leiomyosarcoma of the distal femur in a patient with a history of bilateral retinoblastoma: a case report and review of the literature. Skeletal Radiol. 2003;32(8):476-80.

[11] Wong JR, Morton LM, Tucker MA, Abramson DH, Seddon JM, Sampson JN et al. Risk of subsequent malignant neoplasms in longterm hereditary retinoblastoma survivors after chemotherapy and radiotherapy. J Clin Oncol. 2014;32(29):3284-90.

[12] Jenkinson HC, Winter DL, Marsden HB, Stovall MA, Stevens MC, Stiller CA et al. A study of soft tissue sarcomas after childhood cancer in Britain. Br J Cancer. 2007;97(5):695-9.

[13] Meekins BB, Dutton JJ, Proia AD. Primary orbital leiomyosarcoma A case report and review of the literature. Arch Ophthalmol. 1988;106(1):82-6.

[14] Russell WO, Cohen J, Enzinger F, Hajdu SI, Heise H, Martin RG et al. A clinical and pathological staging system for soft tissue sarcomas. Cancer. 1977;40(4):1562-70.

[15] Nair AG, Kaliki S, Kamal S, Mishra DK, Vemuganti GK Conjunctival Leiomyosarcoma: A Report of Two Cases. Orbit. 2015;34(5):274-8.

[16] Jakobiec FA, Howard GM, Rosen M, Wolff M. Leiomyoma and leiomyosarcoma of the orbit. Am J Ophthalmol. 1975;80(6):1028-42.

[17] Chaugule SS, Putambekar A, Gavade S, Deshpande R. Primary Orbital Leiomyosarcoma in an Adult Male. Ophthalmic Plast Reconstr Surg. 2019;35(2):e27-e29.

[18] Padrón-Pérez N, Mascaró-Zamora F, Gutiérrez-Miguelez C. Can J Ophthalmol. 2013;48(4):65-7. Adjuvant pulse dose rate brachytherapy in a secondary leiomyosarcoma of the orbit.

[19] Folberg R, Cleasby G, Flanagan JA, Spencer WH, Zimmerman LE. Orbital leiomyosarcoma after radiation therapy for bilateral retinoblastoma. Arch Ophthalmol. 1983;101(10):1562-5.

[20] Klippenstein KA, Wesley RE, Glick AD. Orbital leiomyosarcoma after retinoblastoma. Ophthalmic Surg Lasers. 1999;30(7):579-83.

[21] Mihara F, Gupta KL, Kartchner ZA, Kogutt MS, Robinson AE. Leiomyosarcoma after retinoblastoma radiotherapy. Radiat Med. 1991;9(5):183-4.

[22] Font RL, Jurco S 3rd, Brechner RJ. Postradiation leiomyosarcoma of the orbit complicating bilateral retinoblastoma. Arch Ophthalmol 1983;101(10):1557-61

[23] Tselis N, Karagiannis E, Kolotas C, Baghi M, Milickovic N, Zamboglou N. Image-guided interstitial high-dose-rate brachytherapy in the treatment of inoperable recurrent head and neck malignancies: An effective option of reirradiation. Head Neck. 2017;39(4):E61-E68. 
[24] Jakobiec FA, Howard GM, Rosen M, Wolff M. Leiomyoma and leiomyosarcoma of the orbit. Am J Ophthalmol. 1975;80(6):1028-42.

[25] Chew YK, Noorizan Y, Khir A, Brito-Mutunayagam S. Leiomyosarcoma of the maxillary sinus. Med J Malaysia. 2009 Jun;64(2):174-5.

[26] Wojno T, Tenzel RR, Nadji M. Orbital leiomyosarcoma. Arch Ophthalmol. 1983;101(10):1566-8.

[27] Liu JC, Givi B, Wolden S, Kleinerman RA, Dunkel IJ, Lee N et al Secondary skull base malignancies in survivors of retinoblastoma: the memorial sloan kettering cancer center experience. Skull Base. 2011;21(2):103-8

[28] Pendergrass TW, Davis S. Incidence of retinoblastoma in the United States. Arch Ophthalmol. 1980;98(7):1204-10.

[29] Broaddus E, Topham A, Singh AD. Survival with retinoblastoma in the USA: 1975-2004. Br J Ophthalmol. 2009;93(1):24-7. 